\title{
Cyanosis in a male Nigerian infant with acute kidney injury: Questions
}

\author{
Jasmin Pansy • Christoph J. Mache • Gerfried Zobel • \\ Gernot Grangl • Ekkehard Ring • K. Martin Hoffmann
}

Received: 24 June 2013 / Revised: 25 June 2013 / Accepted: 27 June 2013 / Published online: 30 August 2013

(C) IPNA 2013

Keywords Hyperuricemia $\cdot$ Acute kidney injury $\cdot$ Cyanosis

\section{Case summary}

A 10-week-old Nigerian boy was referred to our hospital with a history of feeding difficulties, poor weight gain and recurrent vomiting. The mother had not noticed any changes in the frequency of wet diapers. Family and patient histories were unremarkable except for neonatal jaundice in the propositus. Apart from vitamin D supplementation (400 IU/day) no drug intake was reported. On admission he appeared well and alert, but showed signs of dehydration. Otherwise, physical examination was unremarkable. His weight was 4,660 g; temperature, $36.7^{\circ} \mathrm{C}$; pulse rate, $135 / \mathrm{min}$; blood pressure, $90 / 55 \mathrm{mmHg}$. Laboratory investigations revealed a serum creatinine of 1.98 (normal $0.2-0.5$ ) $\mathrm{mg} / \mathrm{dL}$ and urea of 226 (normal 14-40) $\mathrm{mg} / \mathrm{dL}$. Serum uric acid was 22 (normal 3.6-6) $\mathrm{mg} / \mathrm{dL}$. Acid-base status was normal. Serum $\mathrm{Na}^{+}$was $130 \mathrm{mmol} / \mathrm{L} ; \mathrm{K}^{+}, 4.2 \mathrm{mmol} / \mathrm{L} ; \mathrm{iCa}^{2+}, 1.04 \mathrm{mmol} / \mathrm{L}$; phosphate, 2.92 (normal 1.13-2.13) mmol/L. Blood hemoglobin level was normal (11.6 g/dL). No blasts were visible on peripheral blood smears. Analysis of a urine catheter sample $\left(\mathrm{Na}^{+} 12 \mathrm{mmol} / \mathrm{L}\right.$, osmolality $445 \mathrm{mosmol} / \mathrm{kg}$, protein $/$ creatinine ratio $0.62 \mathrm{~g} / \mathrm{g}$ ) and fractional excretion of sodium $(0.29 \%)$ indicated predominantly prerenal acute kidney injury. Ultrasound showed normal-sized kidneys with medullary hyperechogenicity. Abdominal lymphadenopathy and organomegaly were absent. A chest X-ray was normal.

Isotonic fluid replacement [20 $\mathrm{ml} / \mathrm{kg}$ body weight (BW) intravenously] was started, and a single dose of rasburicase $(0.2 \mathrm{mg} / \mathrm{kg} \mathrm{BW}$ iv) was given. Urine output subsequently increased to $>2 \mathrm{ml} / \mathrm{kg} / \mathrm{h}$ within $1 \mathrm{~h}$. Two and a half hours later routine monitoring by pulse oximetry demonstrated a gradual and continuous decrease in oxygen saturation leveling at a blood oxygen saturation $\left(\mathrm{SpO}_{2}\right)$ of approximately $80 \%$. Chest auscultation was normal, and the patient did not present any signs of respiratory distress. Echocardiography showed normal cardiac filling and biventricular function. Nasal application of oxygen up to $4 \mathrm{~L} / \mathrm{min}$ had no effect on cyanosis.

\section{Questions}

1) What is the most likely cause of cyanosis in this infant?

2) Which diagnostic tests would you perform?

3) How can this condition be avoided?

The answers to these questions can be found at http://dx.doi.org/10.1007/ s00467-013-2568-7.

J. Pansy $(\varangle) \cdot$ C. J. Mache $\cdot$ G. Grangl $\cdot$ E. Ring $\cdot$ K. M. Hoffmann Division of General Pediatrics, Department of Pediatrics and Adolescent Medicine, Medical University of Graz, Auenbruggerplatz 34/2, A-8036 Graz, Austria

e-mail: jasmin.pansy@medunigraz.at

G. Zobel

Pediatric Intensive Care Unit, Department of Pediatrics and Adolescent Medicine, Medical University of Graz, Graz, Austria 